\title{
Influence of Teachers' Competencies on ICT Implementation in Kenyan Universities
}

\author{
Timothy Bariu $(\mathbb{D}$, Xiong Chun, and Azzeddine Boudouaia \\ Central China Normal University, Wuhan, China \\ Correspondence should be addressed to Timothy Bariu; tbariu493@yahoo.com
}

Received 11 January 2022; Revised 14 February 2022; Accepted 16 February 2022; Published 7 March 2022

Academic Editor: Ehsan Rezvani

Copyright (C) 2022 Timothy Bariu et al. This is an open access article distributed under the Creative Commons Attribution License, which permits unrestricted use, distribution, and reproduction in any medium, provided the original work is properly cited.

\begin{abstract}
Teachers' ICT implementation is of growing importance in classrooms; currently, technology has become an essential ingredient of teachers' practice. The study explores the implication of teachers' competencies on ICT implementation in universities. The empirical literature has established a considerable research gap despite teachers' competencies being critical in ICT implementation. The study presents a university survey in Kenya on 475 teachers exploring the implication of teachers' ICT competencies on ICT implementation and teachers' skills and knowledge. The descriptive statistics results indicated a mean of 4.279 and a Spearman correlation of 0.618 between teachers' competencies and use of software tools, implying that teachers' level of competencies increases as they use and employ software tools when teaching. The chi-square test statistic indicated results of 288.498 and a significance of $P<0.005$. The $P$ value is less than the chosen significance level $\alpha=0.05$, which checks for independence on the teachers' competencies on ICT implementation. Therefore, implying that the null hypothesis was rejected at the $5 \%$ level of testing. The conclusion was that there is significant evidence that teachers' competencies significantly influence ICT implementation. Therefore, this study forms a foundation informing all universities stakeholders on their responsibility to support teachers in implementing technology in their instruction.
\end{abstract}

\section{Introduction}

Information Communication and Technology (ICT) implementation in universities has recently gained momentum due to the technological revolution and advancement of the Internet as the medium of communication [1]. Therefore, ICT implementation has attracted the interest of institutions of higher learning, teachers, and the corporate sector. Technology has greatly transformed higher education in the 21st century. According to Ogegbo and Aina [2], the world is currently in the ICT era; thus, information is no longer restricted by time-space and channel. Information Communication Technology (ICT) Implementation in education has created a robust classroom environment that has transformed teaching and learning. Teachers and learners apply knowledge in an active, self-directed, and constructive way [3]. Teachers play an essential role in the effective implementation of one-to-one initiatives, and they bear the responsibility of implementing ICT in the classroom.
Therefore, there is a need to investigate teachers' competencies since overall, teachers integrate ICT into the school. The playing field between student and teacher should be leveled. If there is no ICT integration, there will be a wide generation gap; thus, the importance of this research is to ascertain the teacher's competencies as an influencing factor in ICT implementation.

Mavrina and Mingaleva [4] indicate various ICT interventions in education at institutional, national, regional, and global levels, thus making it easy for ICT to improve the quality of teaching and learning, increasing education accessibility, enhancing social equity, and cultivating inclusive knowledge society across the world. Similarly, Teacher Education for sub-Saharan Africa (TESSA) is a well-tailored program creating multimedia resources for sub-Saharan teachers and teacher educators. The program has made a milestone by introducing $\mathrm{BBC}$ radio programs that debate teachers' roles and responsibilities in improving their skills and acted as a tool kit for education planners and 
stakeholders in designing open and distant learning for tutors in Africa. ICT implementation is a revolutionary tool that has brought meaningful changes in teaching methodologies. Technology has contributed immensely towards learner-centered teaching methods $[5,6]$.

Teachers' competencies on ICT in the 21 st century require a regular update on knowledge and skills to be in tandem with the technology dynamic to implement it in classroom instruction. Collaboration in ICT Knowledge and integration is paramount for the teachers and students to navigate the large amount of information needed to accomplish complex tasks in the world economy [7]. Many developing countries are pressurized to implement ICT in teaching and learning to cope with the skills and knowledge needed in the 21st century [8]. However, the key challenge facing education institutions globally is curriculum transformation to equip learners with the relevant skills needed in the 21st century [9]. Further, despite addressing the teachers' initial anxiety of getting involved in technology, technical support has still been a challenge; however, teachers are advised not to be discouraged by technological failure they do not comprehend [10].

Teachers need to be equipped with relevant ICT competencies, including software with specific applications apart from word processors, data processors, and spreadsheets; the Statistical Package for the Social Sciences (SPSS) analyzes data, thus enhancing output. Therefore, increasing learners' learning experience can access their learning through community education, cultural diversification, and globalization, ensuring no boundary in place and time. Thus, knowledge is student-centered [11]. Further, ICT provides tools needed in the "Information Knowledge Society"; therefore, teachers are compelled to digitally integrate ICT in instruction to empower their students in the 21 st century. ICT enables collaboration, creation, storage, and dissemination of knowledge and resources worldwide [6]. Therefore, with the increasing demand for ICT skills, education institutions must provide learners with essential roles in knowledge dissemination in the current digital world [12].

Teachers' competencies are critical influencers on ICT implementation in institutions of higher learning, as reported by Yang [13]. Similarly, Agarwal [14] posits that training gaps aided by administrators are viewed as an obstacle towards ICT implementation. Storte et al. [15] have categorized ICT implementation into levels such as teachers' competencies, training, and motivation, the school environment on ICT access, and absence of ICT dimension and school system, which explores the system's rigidity that explores more comprehensive educational framework. Therefore, there are conspicuous gaps between policies and changes in classroom exercises that directly affect [16]. Therefore, the implication is that teachers should articulate policies, but unfortunately, they are unaware of the policy themselves or their purposes. Consequently, policies are affected as programs; however, these programs rarely attain an anticipated change in the classroom.

Teachers' roles such as course development, course facilitation, course moderation, and learners' evaluation will significantly change with introducing the innovation [17].
Therefore, the need for teachers to learn the skills enhances their competencies within the learning environment. Wang and $\mathrm{Lu}$ [18] revealed that effective application of policies in the classroom significantly correlated with the teachers' learning with the policy-related document. Similarly, research has established that learning is a process of interception between teachers and learners since they all participate in the learning process; however, the teachers should take the initiative to lead the way since they greatly influence curriculum implementation. However, the empirical review has shown inadequacies of teachers' competencies using ICT tools to develop courses, upload learning materials, facilitate online discussions, and evaluate learners remains unclear [19]. Therefore, there is a need for teachers to possess the prerequisite competencies in teaching and management. Consequently, the study was guided by the following objectives:

(i) To determine the influence of teachers' competencies on university ICT implementation

(ii) To assess the relationship between teachers' competencies and ICT implementation in universities

\section{Purpose of the Study}

According to Uslu [20] for any innovation to be effective and successful, change agents are required key; among them are the teachers since they are the essential medium of instruction. Teachers' competencies greatly influence any innovation and curriculum adjustment that necessitates any change in content and methods [21]. However, effective ICT implementation in universities may not be adequate if university teachers lack the necessary competencies to function adequately in teaching and learning. By assessing the influence of teachers' competencies on ICT implementation in Kenyan universities, the research highlights teachers' competence gaps that impede ICT implementation and addresses the need for appropriate intervention to improve teachers' competencies to enhance access and effective ICT implementation.

\section{Teachers' Competencies}

Teachers' competencies are the confidence, skill, and capability in using ICT for instruction purposes to perform the task appropriately [22]. Teachers' competency is a vital capacity required to implement ICT in teaching and learning. Studies by Emiliani et al. [23] established that the lack of confidence in using ICT in instruction is caused by inadequate knowledge on ICT-related tasks and deficient skills in using ICT software tools and appliances. Brown et al. [24] reiterate that capacity building in education on ICT use should concentrate on sketch multimedia modules borderless training strategy and in-service training using ICT. Therefore, the instructors should be equipped and furnished with relevant knowledge and skills to become more agreeable with technology, the Internet, web design, and projectbased approaches to education. UNESCO [25] teachers' pedagogical integration of ICT is a process with four key 
stages, namely, emerging, which is the application of productivity instruments; applying, which is the intensification of traditional teaching methods; infusing, which is the facilitation of blended learning within or across subject areas; and altering, which is the creation of interactive learning platforms. All this is geared towards equipping instructors to employ ICT in subject teaching, familiarizing ICT tools, and specializing in usage patterns. Similarly, Wolff et al. [26] reiterate that skill and knowledge, if not addressed conclusively, could inhibit the effectiveness of ICT use in teaching and learning.

Further, Xue and Churchill [27] posit that there has been a meaningful improvement in teachers' awareness and transformation of classroom activities after training geared towards educational practices and strategies on ICT application. The findings are consistent with Zha et al. [28] who deduced that instructors with limited ICT training are authoritarian and inefficient, making learning difficult for learners as they view school being repressive. Similarly, research has established that routine use of ICT through teachers' professional development and instruction process correlates with high-level learners' ICT-related skills and experience. Further, teachers' inefficient ICT skills and knowledge influence their competencies in implementation in their institutions. Hofer et al. [29] established that teachers devoid of ICT skills and knowledge do not integrate ICT in teaching and learning. Thus, rendering integration and implementation are an uphill task since instructors with limited experience with ICT fear to try using them, as posited by Yang and Lam [30]. The latter deduced that teachers shy away from integrating ICT in teaching.

Teachers' competencies are the key predictor in ICT implementation in universities. Mabrouk et al. [31] established the correlation of teachers' competencies with their confidence; thus, teachers' confidence relates to the perception of ICT tools in the classroom in relation to their learners' perceived competence. Similarly, teachers' ICT competency correlates with their qualifications; thus, academic qualifications influence ICT implementation. Molteni et al. [32] established that personalities with lower education significantly use ICT tools rarely for various purposes in both developing and developed countries. Marcinkiewicz-Wilk and Jurczyk-Romanowska [33] showed that computer competence correlated with computer use among university lecturers in the United States of America. They, therefore, concluded that computing confidence greatly influenced university preparedness on ICT implementation. Further, [34] established that ICT competence was fundamental to ICT implementation by lecturers in teaching and learning. Therefore, ICT competence by lecturers influenced ICT implementation in the university since lecturers are crucial in enhancing institution capacity to embrace ICT.

3.1. ICT Implementation. Information Communication Technology (ICT) implementation involves the choices and decisions of an individual or a learning institution to adopt a particular technological innovation [35]. The implementation consists in adoption of all necessary procedures to use the technology [36]. Generally, the process should be complete, where all the critical components are put together to make a whole [37]. The ICT implementation procedure uses research tools, evaluation procedures, organization, and information communication [38]. Further, in universities, teaching and learning tools for research and the Internet are widely used [39]. Similarly, other tools like computers, projectors, and audial and visual technology in universities are applied for teaching and learning [40].

Studies on teachers by Garcia et al. [41] established that $85 \%$ had inadequate skills to implement ICT in teaching and learning effectively. Thus, skill competence was regarded as the critical factor limiting ICT implementation in instruction. Similarly, a study by Selim et al. [42] on teachers' acceptance of ICT integration in teaching deduced that skill inadequacy contributed to little confidence in using ICT technology, thus a significant influence in ICT implementation in universities in Malaysia. Further, Agboola et al. [43] investigated the preparedness of university lecturers for the introduction of ICT in the International Islamic University of Malaysia established that confidence and training in ICT was a significant predictor of ICT implementation. Thus, the correlation implied that trained lecturers' exhibited substantial levels of preparedness and demonstrated confidence in integrating ICT. The study further investigated the impacts of background factors such as gender, age, and experience and established that ICT implementation had a weaker correlation; thus, they are not significant.

Studies by $\mathrm{Wu}$ et al. [44] investigated the factors influencing ICT websites adoption in universities. They established that intention to use ICT websites was greatly influenced by the relative advantage of the website, compatibility of the technology, and prior experience in ICT use. Further, lecturers' use of ICT websites was greatly influenced by their competence in using the technological tools. Therefore, ICT competent lecturers exemplified quick accessibility of ICT websites, unlike the incompetent who had challenges. However, the study eluded the affordability and accessibility of ICT infrastructure; therefore, it may not be applicable in developing countries. Further, Konovalova et al. [45] investigated the factors influencing e-learning at a university in Bahrain. The study was premised on the Technology Acceptance Model (TAM), which established that perceived usefulness and ease of use significantly influenced lecturers' use of ICT in teaching.

Further, the findings demonstrated that computer selfefficacy significantly influenced accepting ICT technology. Therefore, the study was necessary to upskill ICT skills and knowledge by the teachers because they greatly influence the ICT perception of both their students and university management. However, the Technology Acceptance Model (TAM) applied in the study was weak in not considering the socioeconomic and cultural factors that determine an individual's technology use orientation [46].

Further, Sobieraj and Krämer [47] investigated the role of gender and social influence in technology acceptance behavior among the academic staff of public universities. They established that men accepted the new technology more than women. Similarly, younger teachers were more 
interested in new technology than the older lecturers. The findings implied that younger teachers were open to new ideas, unlike more senior teachers who were afraid of new technologies and considered them a threat to their careers.

Kalla et al. [48] investigated the factors influencing teachers' computer use in the classroom in selected commonwealth Virginia schools. The study established that personal belief in ICT competence significantly predicted ICT use to support learning. The findings further reiterated that lecturers' competence greatly influences ICT use in teaching and learning. Similarly, Knezek et al. [49] investigated the impact of new ICT on lecturers' function and performance. The study applied an alternative hypothesis that high-level ICT skills result in higher technology integration, thus positively impacting students' achievements. Therefore, the model implied that teachers with higher skills easily influenced their institutions to integrate ICT technology in teaching and learning.

Garousi et al. [50] investigated teachers' attributes on computing skills in Ecuadorian public universities. They established that changing lecturers' negative attitudes is essential for improving competence in ICT implementation in universities. Therefore, for successful ICT implementation in universities, lecturers should possess a positive attitude on ICT tools. The findings further concluded that lecturers could develop a positive attitude when comfortable and knowledgeable with the technology. Additionally, Law and Lynch's [51] study on "worldwide assessment of ICT integration" established that inadequate ICT skills greatly influenced ICT implementation in teaching and learning, with lecturers' adequate knowledge and skills being the critical impediments to technology implementation in learning institutions. Therefore, there is need for addressing the skill challenge among the teachers for efficient ICT implementation in universities.

Luan et al. [52] investigated gender differences in ICT competencies among teachers and teaching staff at University Putra Malaysia. The study used different software tools such as spreadsheets, databases, presentations, electronic mail, World Wide Web (WWW), multimedia, and virtual applications and assessed the differences in competencies among male and female lecturers. The findings established the fact that both female and male teachers had good skills in word processing and e-mailing tools. These results were attributed to frequent utilization of ICT materials, manuscript writing, and general communication. The findings indicated that female lecturers had competence in the use of many software tools in comparison to their male counterparts. For example, female teachers had scored $85 \%$ against $64 \%$ for males in the insertion of texts in the word processing. Further, females scored higher than males in the application of e-mailing tools with $96 \%$ against males with $87 \%$. The findings further established that overall, $64 \%$ of all the lectures had some computer competencies [52].

\section{Theoretical Background}

This research study is premised on Information System (IS) Success Model developed by [53]. The proponent examined the Information System (IS) success literature and developed a comprehensive taxonomy of factors that contribute to the success of the Information System. Further, the IS model involves a combination of hardware and software hardware, training personnel by equipping them with relevant skills and knowledge to facilitate planning, control, coordination, and decision-making in an institution. The factors include the following.

System Quality Factor. It focuses on the use and performance aspects of the system being examined. The overall quality is the common dimension in evaluating the system. It indirectly impacts how the system delivers benefits by mediational relationships through user satisfaction and usage intention resulting from access, convenience, usability, and flexibility.

Information Quality Factor. It focuses on the quality of information that is produced by the system (IS's output) and its usefulness to the user. It is the most common dimension in which the systems are evaluated. It impacts users' satisfaction and intentions to use the system. Thus, an effect on the benefits accrued to the user and institution, for example, the instruction quality in teaching. The factor is measured through availability, adequacy, and IS relevance.

Service Quality Factor. It focuses on the quality of support users receive from management, IS department, and ICT support personnel. The service quality directly impacts user intention and satisfaction with the system, thus impacting the net benefit of the system, for example, policy guidance, training, and technical support. The service quality is measured through users' competency and capability, assurance, and empathy.

Intention to Use or System Use. This is the extent and how an IS is used. It is influenced by information, the system, and the quality of services. The use factor is believed to influence the users' satisfaction with the system, influencing the intention to use. Therefore, intention to use or system use with user's satisfaction directly impacts the net benefits provided by the system. Consequently, it can be measured through the actual use and readiness to use, thus measuring system success.

User Satisfaction. This is the satisfaction and efficiency of IS by an individual or group of users. User satisfaction directly influences the net benefits of the information system. System use is directly affected by the degree to which the user is content with the information system. It is measured by users' enjoyment, attitude, or perception of implementing the system.

Net Benefit Factor. This is the degree to which the IS contributes to individual and organization success. The net system benefits are affected by system use and user satisfaction. The system benefits influence both user satisfaction and intention to use the system. It is measured by the extent of system efficiency or productivity and returns on investment (ROI). 
According to DeLone and McLean [53], the six factors are interrelated and not independent based on causal and process considerations. The factors are indicators for measurement and influential factors whose extent determines the success and productivity of any IS performance. Further, the factors imply measuring, analyzing, and reporting IS success. The model advocates that an IS is first created with various characteristics that exhibit different system and information quality degrees. The managers and users then experience these characteristics through system use; thus, they are either satisfied or dissatisfied with the system. Further, system use and its information impact an individual user in their work, and the individuals' influences result in institutional or organizational impact.

Therefore, this study has adopted the information system success to describe the influence of teachers' competencies on ICT implementation in universities. The taxonomy of the factors in the model is essential for effective ICT implementation in universities (net benefits). The indicator factors applied in this study are university curriculum and government support. They constitute key factors that are fundamental to implementing ICT in universities effectively.

DeLone and McLean's IS success model was published in 1992 and was based on theoretical and empirical IS research done by researchers in the 1970s and 1980s. However, the role of information system (IS) success has tremendously advanced in the last few decades. Further, the model has been researched widely since its publication in 1992 [53,54]. The model applies a multidimensional approach applicable in different ICT implementation contexts. Further, the model has been widely linked to positive outcomes in various studies on factors influencing ICT implementation. Therefore, the study has developed justifiable recommendations on developing applicable teachers' competencies that enhance ICT implementation.

Further research has established that the success of any information system is dependent on the dimensions of IS model. Perceived system quality measured by ease of use, that is, the implementation of ICT, and perceived Information quality measured by availability and adequacy of ICT infrastructure are key predictors in system satisfaction. The perceived system quality, that is, the ease of use of the system, is also an important predictor of system use that is the actual system use. The user satisfaction was found to be a strong predictor of individual impact and institutional net benefit to studies on "Electronic Health Record (EHR)" by [55]. However, the said studies by this model were widely done in different contexts rather than Kenyan universities. Therefore, there is a need for adopting the model and conducting a study to establish the setbacks of effective ICT implementation in Kenyan Universities.

\section{Methodology}

The study adopted a descriptive survey research design. The target population for this study was teachers and university administrators from Chuka University in Kenya. The number sampled was 475 from a sample of 1400 university staff. Data were analyzed using both descriptive and inferential statistics. The analysis used descriptive statics and identified the mean statistics. The correlation was tested using Spearman's rho correlation and Chi-square used for hypothesis testing with the help of the Statistical Package of Social Sciences (SPSS), where a level of significance at 0.05 led to an acceptance of the hypothesis.

5.1. Participants. This study targeted the teachers' population of Kenyan universities. The target population is composed of all teachers and universities' administrators. The population specification that addresses the inquiry affects the researchers' decisions on sampling and resources used [56]. The population is considered a group of individuals, observation, and a test involved in the search problem [57]. According to research, the population is regarded as a distinct component of analysis like a school, institution, or organization [58]. Therefore, the target population of this study included university teachers and university administrators chosen because they are the implementers of the ICT process at the university level.

5.2. Instruments. This study applied the questionnaire method to collect data. A questionnaire is a research instrument for gathering data evaluated against a particular social, educational, and psychological perspective [56]. The questionnaire is distributed to specific people to obtain data on an investigated phenomenon. This research instrument fit the study because it could reach many people with minimal cost and elicited a lot of information. The respondents gave an insight into their feelings, background information, hidden motivation, interest, and decisions. Open-ended questions allowed and stimulated respondents to think about their feelings or motives and to express what they considered to be most important.

5.3. Data Collection Procedure. The researchers sought permission from the National Council of Science, Technology, and Innovation (NACOSTI) and the university administration to conduct the research. Generally, the study was guided by informed consent since research participation is not a straightforward matter and needs permission [59]. In writing, the selected respondents were informed on their option to participate or not to participate. Further, the justification for sampling was clearly explained. The respondents were briefed correctly before completing the questionnaire. The research purpose was to assess teachers' competencies influencing ICT implementation in Kenyan universities.

5.4. Data Analysis. The questionnaires were processed and entered into the computer for analysis. The data was processed through coding the responses to enhance good analysis with the Statistical Package for Social Sciences (SPSS) using descriptive statistics. The study applied Spearman's rho correlation analysis using the correlation coefficient analysis to test hypothesis $\mathrm{Ha}_{1}$, using Spearman's Rho correlation denoted by $r$. A Spearman rho correlation 
analysis investigated an association or variance between teachers' competencies and ICT implementation in Kenyan universities. Further, the chi-square test that checks for independence on the teachers' competencies on ICT implementation statistics helped calculate each response's means, mode, median, and standard deviations in each category.

5.5. Sample Size and Sampling Procedures. The study used a total sample size of 475 individuals for the study drawn from a target population of 11,328 individuals, according to Krejcie and Morgan sample size table. The researchers developed a model for determining sample sizes at different confidence levels and error margins. The 95\% confidence level margin and a sample of 475 subjects were considered an appropriate representation of a population above 10,000 issues but equal to or less than 15,000. Generally, it is argued that the bigger the sample size used, the closer the distribution to an ordinary distribution, referred to as the central limit theorem, which can also occur if the sample is not ordinarily distributed [56].

5.6. Response Rate. According to Mugenda and Mugenda [56], the sample needs to be significant to ensure sufficient responses for the required margin error, and a 100\% response rate is unlikely. There is a need for a high response rate to ensure adequate sample representatives. In this study, the response was due to some respondents' COVID-19 lockdown and restrictions and lack of time. A total of 550 questionnaires were distributed to university teachers and administrators. Out of the 550 questionnaires distributed, $475(86.4 \%)$ were appropriately filled and returned. The rest $75(13.6 \%)$ were not filled and others partially filled; thus, they were discarded during data analysis. Mugenda and Mugenda [56] indicate that a 50\% and above return rate is acceptable in any study. Therefore, a return rate of 475 $(86.4 \%)$ was considered adequate for the study.

5.7. Gender of the Respondents. Generally, Table 1 indicates the gender of the research study respondents. Of the 475 respondents, 250 were males. The results constitute $52.6 \%$. Again 225 females constituted 47.4\%. The implication was that most university teachers involved in ICT implementation in Kenyan universities were men and that most males significantly influenced ICT programs in the institution.

5.8. Age of the Respondents. Table 2 indicates the ages of the respondents. $25.3 \%$ of the respondents were below $30 \%$, $37.9 \%$ were within 31 and 40 years, $24.6 \%$ were between 41 and 50 years, $10.3 \%$ were between 51 and 60 years, and $1.9 \%$ were over 60 years.

5.9. Findings. Table 3 shows descriptive statistics, showing the influence of the teachers' competencies on ICT implementation. The mean statistic is 4.2791 , and Figure 1 gives a
TABLE 1: Gender of the respondents.

\begin{tabular}{|c|c|c|c|c|c|}
\hline & & Frequency & Percent & $\begin{array}{c}\text { Valid } \\
\text { percent }\end{array}$ & $\begin{array}{c}\text { Cumulative } \\
\text { percent }\end{array}$ \\
\hline \multirow{3}{*}{ Valid } & Male & 250 & 52.6 & 52.6 & 52.6 \\
\hline & Female & 225 & 47.4 & 47.4 & 100 \\
\hline & Total & 475 & 100.0 & 100.0 & \\
\hline
\end{tabular}

TABle 2: Age of the respondents.

\begin{tabular}{cccccc}
\hline & & Frequency & Percent & $\begin{array}{c}\text { Valid } \\
\text { percent }\end{array}$ & $\begin{array}{c}\text { Cumulative } \\
\text { percent }\end{array}$ \\
\hline \multirow{4}{*}{ Valid } & Below & 120 & 25.3 & 25.3 & 25.3 \\
& 30 & & & & \\
& $31-40$ & 180 & 37.9 & 37.9 & 63.2 \\
& $41-50$ & 117 & 24.6 & 24.6 & 87.8 \\
& $51-60$ & 49 & 10.3 & 10.3 & 98.1 \\
& Over 60 & 9 & 1.9 & 1.9 & 100.0 \\
Total & 475 & 100.0 & 100.0 & \\
\hline
\end{tabular}

TABle 3: Descriptive statistics of teachers' competencies on ICT implementation.

\begin{tabular}{lc}
\hline \multicolumn{2}{c}{ Teachers' competencies on ICT implementation } \\
\hline Number & 475 \\
valid & 0 \\
Missing & 4.2791 \\
Mean & 02876 \\
Std. error of mean & 62682 \\
Std. deviation & 0.393 \\
Variance & 3.000 \\
Range & 2.000 \\
Minimum & 5.00 \\
\hline
\end{tabular}

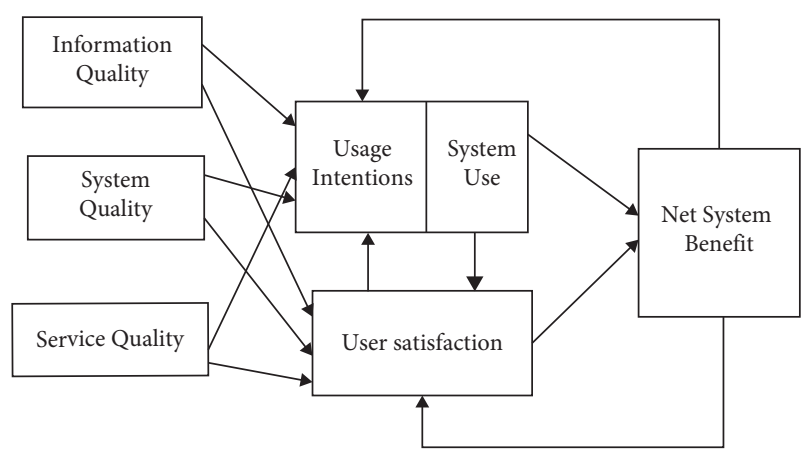

Figure 1: Source: DeLone and McLean [53].

value of 4 when rounded up. The mean value shows that the teachers were competent enough to use ICT in teaching and learning. The majority of the teachers could perform basic ICT tasks, such as switching on and off a computer. They also agreed that they were competent enough to use the Internet for educational materials and scan for viruses. The teachers were also capable enough to use the Internet for e-mail services. They are also competent enough to be using application packages, such as spreadsheets, database management systems, and word processors. 
Table 4 shows a strong positive correlation that is statistically significant that teachers' competencies significantly influence ICT implementation in universities. There is a correlation of 0.618 between teachers' competencies and the use of software tools. The findings indicate that the more teachers use ICT tools, the more competency they use when teaching software tools.

Table 5 highlights the teachers' frequency of use of ICT software tools; the mean statistic of 3.64 and standard deviation of 0.71 translate to significant use of ICT by teachers in learning institutions.

The chi-square test statistic of 288.498 checks for independence on the teachers' competencies on ICT implementation. Therefore, according to the results, the significance is $0.000 P<0.005$. The $P$ value is less than the chosen significance level $\alpha=0.05$, implying the null hypothesis was rejected at the $5 \%$ level of testing. The conclusion is that there is significant evidence that teachers' competencies significantly influence ICT implementation.

\section{Discussion}

The discussion is premised on Information Systems (IS) Success Model developed by [53]. The proponent examined the Information System (IS) success literature and developed a comprehensive taxonomy of factors that contribute to the success of the Information System. Further, the IS model involves a combination of hardware and software, training personnel by equipping them with relevant skills and knowledge to facilitate planning, control, coordination, and decision-making in an institution. This study adopted the Information System Success Model to investigate the influence of teachers' competencies on ICT implementation in Kenyan universities to develop strategies to streamline them for effective ICT implementation.

From the conceptual framework, teachers' ICT competencies constitute key indicators of effective implementation of ICT in universities. Nevertheless, teachers should integrate ICT into their curriculum to enhance access and quality teaching and learning to implement ICT in universities effectively. The IS model by DeLone and McLean's (M\&D) was adopted to derive a conceptual framework that further determines the direction, process, and study outcome. The framework has been customized and domesticated as per the IS model. It has guided the study to establish the influence of teachers' competencies on ICT implementation in Kenyan universities.

Generally, the Information system (IS) Success Model is adopted to guide this study's theoretical and conceptual framework. The six (6) factors in the Information System (IS) success model such as System Quality factor, Information Quality factor, Service Quality; Intention to use or System use, User satisfaction, and Net benefit Factor defines the indicators that are conceptualized in the conceptual framework as key variables that determine the effective implementation of ICT in universities. Further, the Net benefit of the Information system (IS) Success Model, which describes the outcome of information system (IS), has been operationalized in this study to depict the Effective ICT implementation in universities, representing the dependent variable. Thus, the model helps establish the influence of teachers' competencies on ICT implementation.

The findings in Table 3 show descriptive statistics showing the influence of the teachers' competencies on ICT implementation. The mean statistic is 4.2791, and Figure 2 gives a value of 4 when rounded up. The mean value shows that the teachers were competent enough to use ICT in teaching and learning. The majority of the teachers could perform basic ICT tasks such as switching on and off a computer. They also agreed that they were competent enough to use the Internet for educational materials and scan for viruses. The teachers were also capable enough to use the Internet for e-mail services. They are also competent enough to be using application packages such as spreadsheets, database management systems, and word processors.

The findings are consistent with Berner et al. [60], who investigated the factors influencing teachers' computer use in the classroom in selected commonwealth Virginia schools. The study established that personal belief in ICT competencies significantly predicted ICT use to support learning. The findings further reiterated that teachers' competencies greatly influence ICT use in teaching and learning. Similarly, the results agree with Knezek and Christensen [61], who investigated the impact of new ICT on teachers' function and performance. The study applied an alternative hypothesis that high-level ICT skills result in higher technology integration, thus positively impacting students' achievements. Therefore, the model implied that teachers with higher skills easily influenced their institutions to integrate ICT technology in teaching and learning.

Table 4 shows statistically significant evidence that teachers' competencies significantly influence university ICT implementation. There is a correlation of 0.618 between teachers' competencies and the use of software tools. The findings indicate that the more the lecturers become competent, the more they use and employ software tools when teaching. The results agree with studies by Lam and Law [62] on teachers' preparedness for ICT, which established that $85 \%$ had inadequate skills to implement ICT in teaching and learning effectively. Thus, skill competence was regarded as the critical factor limiting ICT implementation in instruction.

Similarly, the results further agree with Eid et al.'s [63] study on teachers' acceptance of ICT integration in teaching, which deduced that skill inadequacy contributed to little confidence in using ICT technology, thus having a significant influence in ICT implementation in universities in Malaysia. Further, Lakshmi et al. [64] investigated the preparedness of university teachers for the introduction of ICT in the International Islamic University of Malaysia established that confidence and training in ICT was significant predictor of ICT implementation. Thus, the correlation implied that trained lecturers' exhibited significant levels of preparedness and demonstrated confidence in integrating ICT.

Table 5 highlights the teachers' frequency of use of ICT software tools; the mean statistic of 3.6411 rounds off to a value of 4 , translating to significant use of ICT by teachers in 
TABLE 4: Correlation table for teachers' competencies on ICT implementation.

\begin{tabular}{|c|c|c|c|c|}
\hline \multicolumn{2}{|l|}{ Spearman's rho } & $\begin{array}{l}\text { Teachers' competencies } \\
\text { on ICT implementation }\end{array}$ & $\begin{array}{l}\text { Rating of competency } \\
\text { on software tools }\end{array}$ & $\begin{array}{c}\text { Frequency of } \\
\text { using ICT }\end{array}$ \\
\hline \multirow{3}{*}{$\begin{array}{l}\text { Teachers' competencies on ICT implementation } \\
\text { Number }\end{array}$} & Correlation coefficient & 1.00 & $0.62^{* *}$ & $-0.46^{* *}$ \\
\hline & Sig. (2-tailed) & 0.00 & 0.00 & 0.00 \\
\hline & & 475 & 475 & 475 \\
\hline \multirow{3}{*}{$\begin{array}{l}\text { Rating of competency on software tools } \\
\text { Number }\end{array}$} & Correlation coefficient & $-0.46^{* *}$ & $-0.67^{* *}$ & 1.00 \\
\hline & Sig. (2-tailed) & 0.00 & 0.00 & 0.00 \\
\hline & & 475 & 475 & 475 \\
\hline \multirow{3}{*}{ Frequency of using ICT } & Correlation coefficient & $-0.62^{* *}$ & 1.0 & $-0.67^{* *}$ \\
\hline & Sig. (2-tailed) & 0.000 & 0.00 & 0.00 \\
\hline & & 475 & 475 & 475 \\
\hline
\end{tabular}

${ }^{* *}$ Correlation is significant at the 0.01 level (2-tailed).

TABle 5: Descriptive statistics on the frequency of use of software tools.

\begin{tabular}{lc}
\hline \multicolumn{2}{c}{ Frequency on the use of software tools } \\
\hline Number & 475 \\
valid & 0 \\
Missing & 3.64 \\
Mean & 0.71 \\
\hline
\end{tabular}

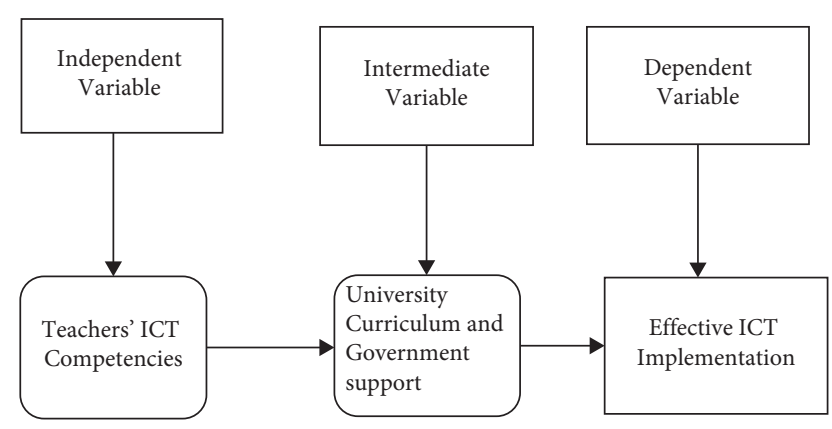

Figure 2: Researcher's construct (2022).

learning institutions. The results correspond with Singh et al. [65], who investigated change levers for unifying top-down and bottom-up approaches to the adoption and Diffusion of e-learning in higher education. The study depended on Giddens' theory of structuration as a theoretical framework. The researchers surveyed five prominent United Kingdom universities to unearth the significant challenges of integrating the top-down and bottom-up approaches to the adoption and Diffusion of e-learning. The theory applied was used to explain the frequency of ICT use and the dynamics of organizational change on the adoption and Diffusion. The findings are intended to support our understanding of the interplay between top-down strategy and bottom-up ICT implementation. The study established that the integrated approach significantly influenced the adoption and diffusion of e-learning in higher learning institutions. Factors like teachers' competence, teaching staff's skill levels, and leadership significantly influenced university ICT use.

Tables 6-8 indicate a chi-square statistic test results of 288.498 checks for independence on the teachers' competencies on ICT implementation. Therefore, according to the
TABLE 6: Model fitting information.

\begin{tabular}{lcccc}
\hline Model & $-2 \log$ likelihood & Chi-square & Df & Sig. \\
\hline Intercept only & 3004.71 & & & \\
Final & 2716.21 & 288.49 & 4 & 0.00 \\
\hline
\end{tabular}

Link function: Logit.

TABle 7: Pseudo R-square.

\begin{tabular}{lll}
\hline & Pseudo $R$-square & \\
\hline Cox and Shell & & 0.46 \\
Nagelkerke & 0.46 \\
McFadden & 0.09 \\
\hline
\end{tabular}

Link function: Logit.

TABle 8: Goodness-of-fit.

\begin{tabular}{lccc}
\hline & Chi-Square & Df & Sig \\
\hline Pearson & 13244.24 & 6388 & 000 \\
Deviance & 2691.646388 & 1.000 & \\
\hline
\end{tabular}

Link function: Logit.

results, the significance is $0.000 P<0.005$. The $P$ value is less than the chosen significance level $\alpha=0.05$, implying the null hypothesis was rejected at the $5 \%$ level of testing. The conclusion is that there is significant evidence that teachers' competencies significantly influence ICT implementation. The results confirm that teachers' competencies substantially influence ICT implementation. The findings agree with Yakubu et al. [66], who investigated factors influencing the adoption and use by university students in developing countries. The study was informed by the unified theory of acceptance and use of technology (UTAUT) and modeled according to survey method collecting data from 286 students of a higher education institution in Nigeria. The data were analyzed using the maximum likelihood of structural equation modeling (SEM) using the IBM Amos 22.0 application. The study's findings indicated that performance expectancy and effort expectancy $(P<0.001)$ were significant factors in influencing the use of Canvas. Thus, facilitating conditions such as competence, knowledge, and behavioral intentions were the most important influencing 
factors that positively impact the actual usage of Canvas by the students. Thus, the study deduces that teachers' competencies significantly influence ICT implementation.

\section{Conclusions}

The study sought to establish the teachers' competencies as an influencing factor on ICT implementation in universities. The study's objectives were to determine the influence of teachers' competencies on ICT implementation in Kenyan universities and assess the relationship between teachers' competencies and ICT implementation in universities. The study hypothesized a significant relationship between teachers' competencies and ICT implementation in Kenyan universities.

Therefore, the study found that teachers' competence greatly influences ICT implantation in universities. The findings indicated a very high statistic mean of 4.2791, showing that the majority of teachers were competent enough to use ICT in the teaching and learning process. Many teachers could perform basic ICT tasks such as switching on and off a computer. Further, the results indicated that many lecturers were competent enough to use the Internet for educational materials and scan for viruses.

Similarly, other teachers could also use the Internet for e-mail services. They are also competent enough to be using application packages, such as spreadsheets, database management systems, and word processors. Further, the value of the chi-square result of 288.498 , with 4 degrees of freedom and a $P$-value of 0.000 which was significant at a 0.01 error margin, confirmed that the teachers' competencies have a substantial influence on ICT implementation. Therefore, it was concluded that teachers' competencies are statistically significant and influence ICT implementation in universities, similarly, with a correlation of 0.618 between teachers' competencies and software tools. It can be concluded that teachers enhance their competence with the continued use of software tools when teaching; thus, they need to familiarize themselves with all ICT tools in instruction.

7.1. Contribution of the Study. The conduct of this study was motivated by the need and realization that ICT implementation has become a necessity in higher education in the current 21st century world. Thus, universities have to redefine their mission on technology innovation in instruction to enhance their competitiveness in the world economy. Therefore, this study provides valuable baseline information to stimulate investment teachers' ICT competencies to streamline university education. Further, Information Communication and Technology (ICT) implementation in universities is a new venture in developing countries; there is a shortage of empirical literature to inform universities on the adoption model. Therefore, this study will benefit many institutions in developing countries to shift from traditional delivery mode to ICT implementation. The study will also contribute to the existing literature on ICT Implementation in universities in developing countries where few systematic studies on ICT have been done. Further, the study incorporated theInformation Systems (IS) Success Model, thus contributing to the model by suggesting a model for addressing many antecedents of theInformation Systems (IS) Success Model applicable in universities in developing countries.

\section{Data Availability}

The data for this research paper is included in the paper and it is readily available from the corresponding author upon request.

\section{Conflicts of Interest}

The authors declare that they have no conflicts of interest regarding the publishing of this paper.

\section{Acknowledgments}

The authors gratefully acknowledge Professor Xiong Chun, an educational professor and a lecturer at Central China Normal University, and Dr. Azzeddine Boudouaia for their contribution to the literature review and data analysis.

\section{References}

[1] S. Memarian, B. Farahani, and E. Nazemi, "Social internet of things: interoperability and autonomous computing challenges," in Proceedings of the 2020 International Conference on Omni-layer Intelligent Systems (COINS), Barcelona, Spain, September 2020.

[2] A. A. Ogegbo and A. Aina, "Early childhood development teachers' perceptions on the use of technology in teaching young children," South African Journal of Chemical Engineering, vol. 10, no. 1, pp. 1-10, 2020.

[3] F. D. Guillen-Gamez, M. J. Mayorga-Fernández, and M. T. Del Moral, "Comparative research in the digital competence of the pre-service education teacher: face-to-face vs blended education and gender," Journal of E-Learning and Knowledge Society, vol. 16, no. 3, pp. 1-9, 2020.

[4] I. Mavrina and A. Mingaleva, "The digitization of the Russian higher education," in Proceedings of the International Conference on Digital Science, Budva, Montenegro, October 2018.

[5] J. Ashton, "Using multimedia to build a sense of community with online distance learners," Journal of Instructional Research, vol. 3, pp. 97-106, 2014.

[6] B. Ogange and A. Carr, "Open educational resources, technology-enabled teacher learning and social justice," Embedding Social Justice in Teacher Education and Development in Africa, Routledge, London, UK, 2021.

[7] N. A. Sheila, C. Zhu, M. J. Kintu, and J. Kataike, “Assessing higher education institutional stakeholders' perceptions and needs for community engagement: an empirical evidence from Uganda," Heliyon, vol. 7, no. 4, Article ID e06612, 2021.

[8] D. Ominde, E. G. Ochieng, and V. O. Omwenga, "Optimising ICT infrastructure performance in developing countries: Kenyan viewpoint," Technological Forecasting and Social Change, vol. 169, Article ID 120844, 2021.

[9] P. Jones, A. Turney, W. Nielsen, and H. Georgiou, "Preparing for teaching digital literacies in the curriculum disciplines," Multimodal Literacies Across Digital Learning Contexts, Routledge, London, UK, pp. 187-213, 2021. 
[10] A. M. Hein and J. Brun, "A conceptual framework for breakthrough technologies," in Proceedings of the Design Society: International Conference on Engineering Design, vol. 1, 2019.

[11] R. M. Homles, B. Gardner, K. Kohm et al., "The relationship between young children's language abilities, creativity, play, and storytelling," Early Child Development and Care, vol. 189, no. 2, pp. 244-254, 2019.

[12] R. Venkatesh, L. Mathew, and T. K. Singhal, "Imperatives of business models and digital transformation for digital services providers," International Journal of Business Data Communications and Networking, vol. 15, no. 1, pp. 105-124, 2019.

[13] X. Yang, "A critical review and analysis: what role of ICT plays in improving professional teachers' English instruction?" Advances in Language and Literary Studies, vol. 10, no. 2, pp. 129-135, 2019.

[14] N. Agarwal, "Quality measures of innovative information communication technology," Cosmos Journal of Engineering \& Technology, vol. 9, no. 1, pp. 5-8, 2019.

[15] D. Storte, M. Webb, R. Bottino et al., "Coding, programming and the changing curriculum for computing in schools," 2019, https://www.researchgate.net/publication/330994753.

[16] N. Cohen and N. F. Aviram, "Street-level bureaucrats and policy entrepreneurship: when implementers challenge policy design," Public Administration, vol. 99, no. 3, pp. 427-438, 2021.

[17] H. Afshari, Z. Amirian, and M. Tavakoli, “Applying group dynamic assessment procedures to support EFL writing development: learner achievement, learners' and teachers' perceptions," Journal of Writing Research, vol. 11, no. 3, 2020.

[18] Y. Wang and H. Lu, "Validating items of different modalities to assess the educational technology competency of preservice teachers," Computers \& Education, vol. 162, Article ID 104081, 2021.

[19] E. M. Andafu, A. K'Odhiambo, and S. Gunga, "A philosophical justification for a paradigm shift to the metaphysical approach in combating examination malpractices among teachers in Kenya," International Journal of Education and Resarech, vol. 7, no. 2, pp. 1-10, 2019.

[20] O. Uslu, "Factors associated with technology integration to improve instructional abilities: a path model," Australian Journal of Teacher Education, vol. 43, no. 4, pp. 31-50, 2018.

[21] O. Erstad and J. Voogt, "The twenty-first century curriculum: issues and challenges," Springer International Handbooks of Education, Springer Cham, New York, NY, USA, pp. 19-36, 2018.

[22] S. G. Jordan, J. B. Robbins, D. Sarkany et al., “The Association of program directors in radiology well-being 2019 survey: identifying residency gaps and offering solutions," Journal of the American College of Radiology, vol. 16, no. 12, pp. 17021706, 2019.

[23] F. Emiliani, A. Contarello, S. Brondi, L. Palareti, S. Passini, and D. Romaioli, "Social representations of "normality": everyday life in old and new normalities with covid-19," Papers on Social Representations, vol. 29, no. 2, 2020.

[24] A. Brown, J. Harper, R. Hoppe, E. Janeczko, and E. Vasiljevic, "Digital learning trends and promising practices in wisconsin public school districts," in Proceedings of the Paper presented at the Workshop in Public Affairs, The University of Wisconsin, Madison, WI, USA, May 2019.

[25] UNESCO, Teacher Training and Usage of ICT in education. New Directions for the UIS Global Data Collection in the Post-
2015 Context, UNESCO Institute for Statistics, Montreal, Canada, 2011.

[26] A. Wolff, M. Barker, L. Hudson, and A. Seffah, "Supporting smart citizens: design templates for co-designing data-intensive technologies," Cities, vol. 101, Article ID 102695, 2020.

[27] S. Xue and D. Churchill, "Teachers' private theories and their adoption of affordances of mobile social media: a qualitative multi-case study of teachers' integration of WeChat in higher education in China," Educational Media International, vol. 57, no. 3, pp. 208-232, 2020.

[28] S. Zha, Y. Jin, P. Moore, and J. Gaston, "Hopscotch into coding: introducing pre-service teachers computational thinking," TechTrends, vol. 64, no. 1, pp. 17-28, 2020.

[29] S. I. Hofer, N. Nistor, and C. Scheibenzuber, "Online teaching and learning in higher education: lessons learned in crisis situations," Computers in Human Behavior, vol. 121, Article ID 106789, 2021.

[30] W. Yang and P. T. Lam, "An evaluation of ICT benefits enhancing walkability in a smart city," Landscape and Urban Planning, vol. 215, Article ID 104227, 2021.

[31] M. T. Mabrouk, A. Kheiri, and M. Feidt, "A systematic procedure to optimize integrated solar combined cycle power plants (ISCCs)," Applied Thermal Engineering, vol. 136, pp. 97-107, 2018.

[32] U. Molteni, M. Simon, M. Heinritzi et al., "Formation of highly oxygenated organic molecules from $\alpha$-pinene ozonolysis: chemical characteristics, mechanism, and kinetic model development," ACS Earth and Space Chemistry, vol. 3, no. 5, pp. 873-883, 2019.

[33] A. Marcinkiewicz-Wilk and E. Jurczyk-Romanowska, "The development and implementation of ideas of lifelong learning in Europe at the dawn of the 21st century," Journal of Education, Culture and Society, vol. 9, no. 1, pp. 39-49, 2018.

[34] M. Leenknecht, L. Wijnia, M. Köhlen, L. Fryer, R. Rikers, and S. Loyens, "Formative assessment as practice: the role of students' motivation," Assessment \& Evaluation in Higher Education, vol. 46, no. 2, pp. 236-255, 2021.

[35] C. Buabeng-Andoh, "Exploring university students' intention to use mobile learning: a research model approach," Education and Information Technologies, vol. 26, pp. 241-256, 2021.

[36] R. A. Khan and M. Jawaid, "Technology enhanced assessment (TEA) in COVID 19 pandemic," Pakistan Journal of Medical Sciences, vol. 36, no. COVID19-S4, 2020.

[37] D. Davies, A. Howe, C. Collier, R. Digby, S. Earle, and K. McMahon, Teaching Science and Technology in the Early Years, Routledge, Oxfordshire, UK, 2019.

[38] N. C. Sifakis, L. Lopriore, M. Dewey et al., "ELF-awareness in ELT: bringing together theory and practice," Journal of English as a Lingua Franca, vol. 7, no. 1, pp. 155-209, 2018.

[39] S. C. Pan, F. Sana, J. Samani, J. Cooke, and J. A. Kim, "Learning from errors: students' and instructors' practices, attitudes, and beliefs," Memory, vol. 28, no. 9, pp. 1105-1122, 2020.

[40] T. N. Bariu, "Status of ICT infrastructure used in teaching and learning in secondary schools in meru county, Kenya," European Journal of Interactive Multimedia and Education, vol. 1, no. 1, Article ID e02002, 2020.

[41] A. L. Garcia, N. Athifa, E. Hammond, A. Parrett, and A. Gebbie-Diben, "Community-based cooking programme "Eat Better Feel Better" can improve child and family eating behaviours in low socioeconomic groups," Journal of Epidemiology \& Community Health, vol. 74, no. 2, pp. 190-196, 2020. 
[42] H. M. Selim, R. Eid, and G. Agag, "Understanding the role of technological factors and external pressures in smart classroom adoption," Education + Training, vol. 62, 2020.

[43] M. G. Agboola, K. A. Awobajo, S. O. Oluwatobi et al., "Effect of digitalization on the performance of commercial banks in Nigeria," IOP Conference Series: Earth and Environmental Science, vol. 331, 2019.

[44] D. Wu, C.-C. Li, W.-T. Zhou, C.-C. Tsai, and C. Lu, "Relationship between ICT supporting conditions and ICT application in Chinese urban and rural basic education," Asia Pacific Education Review, vol. 20, no. 1, pp. 147-157, 2019.

[45] S. A. Konovalova, N. G. Tagiltseva, O. O. Aksarina, and S. V. Ward, "Information technology in teaching future pop vocalists to promote their creativity at the university," Smart Education and E-Learning, vol. 240, pp. 229-237, 2021.

[46] E. M. Fox, "Mobile technology: a tool to increase global competency among higher education students," International Review of Research in Open and Distance Learning, vol. 20, no. 2, 2019.

[47] S. Sobieraj and N. C. Krämer, "Similarities and differences between genders in the usage of computer with different levels of technological complexity," Computers in Human Behavior, vol. 104, Article ID 106145, 2020.

[48] H. Kalla, D. Berner, and J.-P. Talpin, "Automated generation of synchronous formal models from SystemC descriptions," Journal of Circuits, Systems, and Computers, vol. 28, no. 4, Article ID 1950061, 2019.

[49] G. Knezek, R. Christensen, and T. Furuta, "Validation of a teacher educator technology competencies survey," Journal of Technology and Teacher Education, vol. 27, no. 4, pp. 465-498, 2019.

[50] V. Garousi, A. Rainer, P. Lauvås Jr., and A. Arcuri, "Softwaretesting education: a systematic literature mapping," Journal of Systems and Software, vol. 165, Article ID 110570, 2020.

[51] K. H. Law and J. P. Lynch, "Smart city: technologies and challenges," IT Professional, vol. 21, no. 6, pp. 46-51, 2019.

[52] H. Luan, P. Geczy, H. Lai et al., "Challenges and future directions of big data and artificial intelligence in education," Frontiers in Psychology, vol. 11, 2020.

[53] W. H. DeLone and E. R. McLean, "Information systems success: the quest for the dependent variable," Journal of Managment Information Systems, vol. 3, pp. 60-95, 1992.

[54] S. Petter, W. DeLone, and E. McLean, "Measuring information systems success: models, dimensions, measures, and interrelationships," European Journal of Information Systems, vol. 17, no. 3, pp. 236-263, 2008.

[55] S. Rahi, M. M. Khan, and M. Alghizzawi, "Factors influencing the adoption of telemedicine health services during COVID19 pandemic crisis: an integrative research model," Enterprise Information Systems, vol. 15, no. 6, pp. 769-793, 2021.

[56] O. Mugenda and A. Mugenda, Research Methods; Qualitative and Quantitative and Mixed Methods Approaches, Sage, Thousand Oaks, CA, USA, 2019.

[57] C. Waddell, K. Georgiades, L. Duncan et al., "2014 Ontario child health study findings: policy implications for Canada," Canadian Journal of Psychiatry, vol. 64, no. 4, pp. 227-231, 2019.

[58] O. Bougie, J. Healey, and S. S. Singh, "Behind the times: revisiting endometriosis and race," American Journal of Obstetrics and Gynecology, vol. 221, no. 1, 2019.

[59] G. Peat, A. Roriguez, and J. Smith, "Interpretive phenomenological analysis applied to healthcare research," EvidenceBased Nursing, vol. 22, no. 1, pp. 7-9, 2019.
[60] J. Berner, M. Aartsen, and D. Deeg, "Predictors in starting and stopping Internet use between 2002 and 2012 by dutch adults 65 years and older," Health Informatics Journal, vol. 25, no. 3 , pp. 715-730, 2019.

[61] G. Knezek and R. Christensen, "Researching impact: measuring technology enhanced outcomes from the NASA space science education consortium," Journal of Computers in Mathematics and Science Teaching, vol. 39, no. 4, pp. 399-420, 2020.

[62] C. Lam and R. Law, "Readiness of upscale and luxury-branded hotels for digital transformation," International Journal of Hospitality Management, vol. 79, pp. 60-69, 2019.

[63] R. Eid, A. Badewi, H. Selim, and H. El-Gohary, "Integrating and extending competing intention models to understand the entrepreneurial intention of senior university students," $E d$ ucation and Training, vol. 61, 2019.

[64] Y. V. Lakshmi, J. Das, and I. Majid, “Assessment of e-Learning readiness of academic staff \& students of higher education institutions in Gujarat, India," Indian Journal of Educational Technology, vol. 2, no. 1, 2020.

[65] M. Singh, S. O. Adebayo, M. Saini, and J. Singh, "Indian government E-learning initiatives in response to COVID-19 crisis: a case study on online learning in Indian higher education system," Education and Information Technologies, vol. 26, no. 6, pp. 7569-7607, 2021.

[66] M. N. Yakubu, S. I. Dasuki, A. M. Abubakar, and M. M. O. Kah, "Determinants of learning management systems adoption in Nigeria: a hybrid SEM and artificial neural network approach," Education and Information Technologies, vol. 25, no. 5, pp. 3515-3539, 2020. 